\title{
THE CRITICAL AND DOGMATIC AGENDA OF ALBERT SCHWEITZER'S THE QUEST OF THE HISTORICAL JESUS
}

\author{
S.J. Gathercole
}

\section{Summary}

This article seeks to explore the twofold agenda of Schweitzer's The Quest for the Historical Jesus. The first element is well-known and obvious: Schweitzer's intention to put to death the 'liberal German' Jesus and to reinstate the true historical Jesus whose preaching and actions were wholly eschatological in orientation. The second element lies below the surface, and this article argues that Schweitzer structured the book around Reimarus, Strauss, Weiss and himself, as they aim to show the impossibility of maintaining Jesus' own dogmatic construction of eschatology in the modern era. It is also demonstrated (against some current understandings) that Schweitzer's reconstruction of Jesus' eschatology does not simply involve Jesus' belief in the end of the space-time universe.

\section{Introduction}

The translator's introduction to Schweitzer's The Mystery of the Kingdom of God, his earliest work, describes the initial reaction of the German theological establishment to him.' ${ }^{1}$ Schweitzer's maverick dissertation was seriously questioned by two members of the Strassburg faculty who examined it: there was concern that Schweitzer's 'sort' of historical research would confuse students. Fortunately, the authority of his Doktorvater, H.J. Holtzmann

1 The dissertation qualified Schweitzer for the position of Privat-dozent at Strassburg and was published as: Das Messianitäts- und Leidensgeheimnis. Eine Skizze des Lebens Jesu (Tübingen: Mohr, 1901). This was translated by W. Lowrie, along with his 'Translator's Introduction', as The Mystery of the Kingdom of God: The Secret of Jesus' Messiahship and Passion (London: A. \& C. Black, 1914) and reprinted in Ausgewählte Werke in fünf Bänden. Band 5 (Berlin: Union Verlag, 1971), pp. 195-340. 
guaranteed its acceptance, even though Holtzmann was one of the principal opponents in the thesis. ${ }^{2}$ When it came to be published, in 1901, the dissertation was greeted with 'oblivion', 'passive hostility', and 'a conspiracy of silence' by the German theological community. ${ }^{3}$ But it was Schweitzer's The Quest of the Historical Jesus (Von Reimarus zu Wrede), published five years later, ${ }^{4}$ which broke the silence that surrounded his eschatological interpretation of the ministry of Jesus, and in Lowrie's words, 'compelled attention'. 5

The structure of The Quest of the Historical Jesus, and particularly the focus on the four key figures of Reimarus, Strauss, Johannes Weiss and Schweitzer himself, was part of the key to its success. What persuaded both German and Anglo-American scholarship to take Schweitzer seriously was the masterful way in which he constructed the history of scholarship up to his own time of writing, and the way in which he used that constructed history. It was the way Schweitzer arranged his history of research that 'compelled attention'.

This structure is the main object of investigation here, and particular attention will be paid to Schweitzer's use of narrative in his construction of the quest. Along the way, we will look at how each of these four figures describes Jesus' eschatological views, and then what they themselves thought eschatology was really about. By looking at how each of these four treats the historical-critical issue of Jesus's eschatology and the dogmatic issue of what that meant for the nineteenth century, we will be able to explore the relation between the critical agenda and the dogmatic agenda that is at work in Schweitzer's narrative. This will also require clarification of

2 A. Schweitzer, Aus meinem Leben und Denken, reprinted in Ausgewählte Werke. Band 1, p. 59.

3 Lowrie, 'Translators's Introduction', pp. 17-19.

4 A. Schweitzer, Von Reimarus zu Wrede: Eine Geschichte der Leben-JesuForschung (Tübingen: Mohr, 1906). The second edition is simply entitled Geschichte der Leben-Jesu-Forschung, reprinted in Ausgewählte Werke. Band 3. The first edition was translated into English by W. Montgomery entitled The Quest of the Historical Jesus (London: Unwin Brothers, 1910, and numerous reprints). Quotations here are from the first German edition and this English translation: it is this first edition which has exercised the most influence within English-speaking scholarship. For an overview of responses to Schweitzer's portrait of Jesus, see W.P. Weaver, The Historical Jesus in the Twentieth Century (Harrisburg, PA: Trinity Press International, 1999), pp. 31-38. The publication by SCM of the 2nd German ed. of 1913 (ET by Susan Cupitt and John Bowden) is imminent.

5 Lowrie, 'Translators's Introduction', p. 19. 
Schweitzer's view of Jesus's eschatology, as this has been slightly misunderstood for some time in the English-speaking world.

The reasons which Schweitzer presents for writing Quest are twofold. In his autobiography, he describes talking to students at Strassburg who went to Friedrich Spitta's lectures on the life of Jesus. Spitta, however, dealt with no history of research at all, ${ }^{6}$ so Schweitzer was motivated to produce a textbook. In Quest, he also describes this gap in the scholarly market. ${ }^{7}$ But in reality, Schweitzer's aims were not merely to fill up a lacuna in scholarship, or to produce a student course-book: his goal was nothing short of a paradigm shift in his discipline. The aim was to destroy the portrait of the Jesus of liberal German theology which tried to make him a nineteenth-century figure who could be a relevant example, and to reinstate the real historical Jesus, who for Schweitzer was an apocalyptic prophet who attempted (heroically, but unsuccessfully) to bring an end to world history. ${ }^{8}$ What liberal German theology had conspired against, for Schweitzer, was the eschatology which was at the forefront of Jesus's thought and teaching. But Schweitzer had a further aim still: to destroy dogmatically what had been reestablished critically. ${ }^{9}$ There are four heroes in the book, including Schweitzer himself: they are all radical iconoclastic thinkers who establish the reality of the eschatological aims of Jesus. But all are personally dismissive of those aims, and seek to establish a worldview and an authority basis distinct from the (eschatological) dogma of Jesus himself.

Two introductory points, to begin. First, there is the German context of the book: Schweitzer's Quest is a response to the very nature of German theology, and deals with what at the time were specifically German issues. As Neander says of his own Life of Jesus Christ half a century before Schweitzer: 'This book has arisen (and it bears the marks of its origin) amid the intellectual struggles which yet agitate Germany, and constitute a preparatory crisis for the

6 Schweitzer, Aus Meinen Leben und Denken, pp. 59-60.

7 Schweitzer, 'Vorwort', Von Reimarus zu Wrede, p. vii: 'Dieses Buch möchte eine Lücke in der theologischen Literatur ausfüllen...' (This Foreword is not in the ET). Cf. also p. 11: 'Es fehlt ein Versuch, Ordnung in das Chaos der LebenJesu zu bringen'.

8 Schweitzer describes the aim of Das Messianitäts- und Leidensgeheimnis in these terms (Ausgewählte Werke. 5, p. 340) and the aim of Quest is in fact the same.

9 In contrast to D.F. Strauss's desire to 're-establish dogmatically what has been destroyed critically' (The Life of Jesus Critically Examined [ET George Eliot; Minneapolis: Fortress, 1972], p. 757). 
future. Those who are unacquainted with those struggles may, perhaps, take offence at finding not only many things in the book hard to understand, but also views at variance with old opinions in other countries yet undisturbed.' 10 The same could well have been said of Schweitzer's Quest - could have been said, when the book was first published; but it is a mark of the astonishing success of Schweitzer's book that the problems which he identified are now recognised much further afield than German-speaking scholarship.

Nevertheless, it will be useful to see how Schweitzer identifies what he sees as the peculiarly German context of the quest, even though the importance of the issues at stake, and the seriousness of the attempt confer on this German quest a place in the history of ideas in general:

When, at some future day, our period of civilisation shall lie, closed and completed, before the eyes of later generations, German theology will stand out as a great, a unique phenomenon in the mental and spiritual life of our time... And the greatest achievement of German theology is the critical investigation of the life of Jesus. (Quest, 1)

But it is impossible to over-estimate the value of what German research upon the life of Jesus has accomplished. It is a uniquely great expression of sincerity (eine einzigartig grosse Wahrhaftigkeitstat), one of the most significant events in the whole mental and spiritual life of humanity. (Quest, 397)

Schweitzer's text is very much a German narrative: it can only be described as comprehensive insofar as it covers the history of German research on the topic. ${ }^{11}$ And Schweitzer's rhetoric aside, he does not explain why the German quest is so unique and significant for world history. Moreover, for all Schweitzer's admiration for his predecessors both at the beginning and the end of his text, it is ambivalence towards this national project which drives so much of Schweitzer's interest. On the one hand, there is its great achievement: Schweitzer constructs a temporal schema for German

10 A. Neander, 'To My Christian Brethren in the United States of America' (Author's Preface to the English Translation), The Life of Jesus Christ in Its Historical Connexion and Historical Development (Translated from the fourth German edition; London: Bohn, 1857), p. viii.

11 Schweitzer has received due criticism for this. See J.W. Bowman, 'The Quest of the Historical Jesus', Interpretation 3 (1949), 188-89, and D.L. Pals, The Victorian Lives of Jesus (Trinity University Monograph Series in Religion VII; San Antonio: Trinity University, 1982), pp. 9-10: 'on Britain's quest neither Schweitzer nor his successors in the field of biblical study, nor the students of Victorian thought and culture, have had much to say'. The only major exception to Schweitzer's rather parochial approach is his treatment of Ernest Renan. 
theology where the study of the history of dogma constitutes its past, and the creation of new dogma its present. The study of the life of Jesus, however, is its future (Quest, 2). On the other hand, Schweitzer considered that the quest in many ways was the struggle of the German spirit against the Spirit of Jesus. The worst offenders were David Friedrich Strauss (1865) and Gustav Frenssen (1905). Frenssen's Jesus is supposed to bring about a rebirth of the German people, but he is in fact just 'a creation of the Germanic spirit in pursuit of a religious will-o'-the-wisp' (Quest, 309). ${ }^{12}$ Strauss's failure is all the more marked as a result of the brilliance of his earlier work; his later work is, by his own admission, a book 'thoroughly well adapted for Germans'. ${ }^{13}$ Schweitzer's main point-almost of the entire book-is that 'historical criticism had become, in the hands of most of those who practised it, a secret struggle to reconcile the German religious spirit with the Spirit of Jesus of Nazareth' (Quest, 310). Schweitzer's aim was divorce, rather than reconciliation. As is well known, he sought to restore the otherness of the Jesus of the Gospels, to distinguish sharply between Jesus's first-century Jewish context and that of nineteenth-century German theology. The regeneration of the German people could not take place on the basis of historical error: that would merely result in violence to both religion and history. ${ }^{14}$

Secondly, there is Schweitzer's concern to bring 'order into the chaos' (Quest, 12): to arrange the scores of lives of Jesus into a scheme that showed their interrelation. He fares brilliantly in the work of systematising, and manages remarkable comprehensiveness, including as he does women's lives of Jesus, the Catholic works, and the Lives which argued for Buddhist influence on the ideas of Jesus: many works which his contemporaries would not have considered worth including. Schweitzer blends what would have been considered the mainstream and marginal by showing their relations in terms of the deep structure of the issues at stake. 15

Schweitzer brings order most fundamentally with a beginning, middle, and end of the quest. Hermann Samuel Reimarus is the initiator of the project at the end of the eighteenth century, when the fragments of his historical investigations were published

12 Von Reimarus zu Wrede, p. 308: 'eine Schöpfung des germanischen Geistes auf religiösen Irrwegen'.

13 Strauss, concluding the preface of his new Life of Jesus, cited in Quest, 193.

14 Quest, 311.

15 Quest, 12. 
posthumously by Lessing. David Friedrich Strauss is the mid-point, with his thorough application of the mythical approach to the Gospels. The final phase is that of Johannes Weiss, whose basic position is followed and developed by Schweitzer himself. These figures are not merely markers along the way, however: almost every scholar who makes a contribution to the quest at any stage is defined in terms of one or more of these three. Progress is made as the ideas of these three are rediscovered or anticipated.

\section{Hermann Samuel Reimarus}

Reimarus occupies a crucial starting-point in Schweitzer's schema for two reasons. Primarily, he was the first to approach the life of Jesus from a purely historical point of view, which for Schweitzer meant engaging in a critical approach to the sources, ${ }^{16}$ and explaining events from a non-supernaturalist standpoint. Second, Schweitzer portrays Reimarus as the first to grasp that the mindset of Jesus, and the world in which he moved was an eschatological one expecting the dawning of the Kingdom of God.

Reimarus was a paradoxical character. His work published in his lifetime reveals nothing of the scepticism revealed in the Fragments, and he remained a regular communicant in the Lutheran church all his life. Reimarus came from an old clergy family, and after his death, there was great hesitancy in associating his name with the manuscript of the Apology in Defence of the Rational Worshippers of God (Apologie oder Schutzschrift für die vernünftigen Verehrer Gottes). The seventh fragment of the Apology (On the Intention of Jesus and His Disciples or Von dem Zwecke Jesu und seiner Jünger) was published posthumously by Lessing in June 1778.17 'It exploded like a bombshell. Never before in Germany had the New Testament been subjected to such radical criticism.' 18 At the beginning of the work, Reimarus articulates Jesus' basic intention (summed up in

\footnotetext{
16 Not that Reimarus assessed the relative historical value of each gospel, rather that he looked at each gospel's account of various events.

17 Von dem Zwecke Jesu und seiner Jünger. Noch ein Fragment des wolffenbüttelschen Ungenannten, ed. Gotthold Ephraim Lessing (Braunschweig, 1778). Two English editions appeared in the same year: C.H. Talbert, ed. Reimarus: Fragments (ET Ralph S. Fraser; Lives of Jesus Series; Minneapolis: Fortress, 1970); G.W. Buchanan, Hermann Samuel Reimarus: The Goal of Jesus and His Disciples (Leiden: Brill, 1970).

18 A. Altmann, Moses Mendelssohn: A Biographical Study (London: Routledge \& Kegan Paul, 1973), p. 563.
} 
verses such as $\mathrm{Mk} .1: 15)$ to preach repentance, and to announce the Kingdom of "God (I, $\S \S 4-5)$. These are connected in so far as 'repentance is the means or preparation for this Kingdom' (I, §4). In line with the Jewish expectation of the time, when the Messiah came, the Kingdom was imminent (I, §§8-9). Subsequently, Reimarus tries to show that the standard orthodoxy of his day had completely misunderstood key doctrines such as 'Son of God', the Trinity, the Holy Spirit, baptism and communion. Reimarus relates all these to his discussion of the Kingdom (I, §28). Since, according to Reimarus, the concept of the Kingdom is never explained, it must be understood in terms of its Jewish background-a this-worldly hope. If only the people of Jerusalem had responded to Jesus' call, then he could install his seventy disciples in the Sanhedrin, and sit himself on David's throne, thus realising God's reign (II, §8). The kingdom (and it is here that Strauss and Schweitzer are critical of Reimarus) was to be brought in by active revolution. But Jesus' attempt was a failure.

At the end of Book I and throughout Book II, Reimarus explains his delicate argument about the difference between the mindsets of Jesus and the disciples. Hence On the Intention of Jesus and His Disciples has two parts. The gospel writers have attempted to eradicate the political character of Jesus's expectation, hoping to replace it with a future, spiritual Kingdom (I, §§31-33) though they have, carelessly, left some clues behind. In Book II $\S \S 1-9$ Reimarus continues with his exposition of the this-worldly expectation, which is then contrasted with the disciples' newly invented ideas. They did this for the money, Reimarus concludes (II, §§52-60).

But Reimarus does not reconstruct Jesus's aims in this way to promote a radical political theology. He is, rather, concerned to argue that the Bible is full of contradictions, ${ }^{19}$ and so cannot be the basis of true religion. Only reason can supply this basis: Reimarus was criticised by Schweitzer for dwelling in 'the desert of the most barren natural religion' ${ }^{20}$ There is not space here to explain in detail Reimarus's conceptions and criticisms of eschatology. Simply put, he was a vigorous defender of the immortality of the soul,21 but

19 See especially the separate fragment on the resurrection (also published in Talbert's volume).

20 Quest, 171.

21 Reimarus argued that the books of the OT were not written to reveal a religion, because they have no doctrine of the future life. See Talbert, 'Introduction' to Fragments, p. 21. 
violently opposed to apocalyptic eschatology: the Book of Revelation, for example, is a book that is worthless for us today. ${ }^{22}$

Three points can be made about Schweitzer's use of Reimarus, and his role in the quest. First, Schweitzer's choice of Reimarus as a starting point does not do justice to the Fragmentist's forebears. As a number of scholars have noted, Reimarus's ideas are heavily dependent on the English Deists, and there was also a sceptical Dutch school in the 18th Century. ${ }^{23}$ As Colin Brown puts it, 'If we look at Reimarus' work against the background of late seventeenthcentury and early eighteenth century thought, it no longer appears, as it did to Albert Schweitzer, as something new, revolutionary and epoch-making. ${ }^{24}$ Reimarus is more of a pioneer in the German context, as one of the first to introduce the radical ideas from England to the continent. And it is not just Reimarus' scepticism that had been preempted: Semler had published his view of the eschatological mindset of Jesus before Reimarus. ${ }^{25}$ So Schweitzer's work begins with a false start.

Secondly, there is another sense in which Reimarus is a false start in the quest, though this time it is by Schweitzer's design. 'Reimarus was the first, after eighteen centuries of misconception, to have an inkling of what eschatology really was. Then theology lost sight of it again' (ET 23). Reimarus is no standard opening chapter. He does not give birth to the idea which a sequence of disciples gradually build on until it is fully developed. Rather, the idea springs fullygrown from his head, and then is heard no more. Reimarus had no

22 'Un livre, aujourd'hui, sans valeur', in P. Grappin, 'La Théologie Naturelle de Reimarus', Etudes Germaniques 6 (1951), 178.

23 See especially C. Brown, Jesus in European Protestant Thought: 1778-1860 (Durham, NC: The Labyrinth, 1985), pp. 36-52; W.G. Kümmel, The New Testament: A History of the Investigation of Its London: SCM, 1973), p. 90; K. Scholder, The Birth of Modern Critical Theology: Origins and Problems of Biblical Criticism in the Seventeenth Century (London: SCM, 1990).

24 Brown, Jesus in European Protestant Thought, p. 50; cf. Talbert, 'Introduction' to Reimarus: Fragments, p. 40.

25 See esp. G. Hornig, Die Anfänge der historisch-kritischen Theologie. Johann Salomo Semlers Schriftverständinis und seine Stellung zu Luther (Lund: Berlingska, 1961), p. 227, n. 47: 'Unabhängig von Reimarus und bereits vor der Publizierung der Fragmente durch Lessing war jedoch das eschatologische Problem auch in den Blickpunkt der historisch-kritischen Forschung Semlers getreten'. Cf. Talbert, 'Introduction', p. 40, n. 86: 'Semler had seen the basic eschatological character of the preaching of Jesus and the early Church...Reimarus was hardly the innovator that Schweitzer made him out to be.' Talbert makes reference to Hornig here. 
disciples: the immediate result of the publication of the Wolffenbüttel Fragments is a spate of hostile responses. ${ }^{26}$

But thirdly, Reimarus is a beginning in the sense that his work is proleptic. Almost a century later comes Strauss, and later still come Weiss and Schweitzer also bringing a resurrection of Reimarus's discovery of eschatology. On the Intention of Jesus and His Disciples is 'the magnificent overture in which are announced all the motifs of the future historical treatment of the life of Jesus' (Quest, 26). Schweitzer's modes of narration are particularly informative here. In his description of the role of Reimarus in the quest he makes considerable use of authorial hindsight: Schweitzer look backs, and sees the effective history of Reimarus's views. But he also creates the illusion of a predetermined scheme, as in the overture metaphor, and, even more starkly, in the description of Reimarus anticipating Weiss's ideas 'with prophetic insight into the future'.27 With the trope of prophecy, Schweitzer fuses narratorial hindsight with the impression of a predetermined scheme. The effect is that Schweitzer acquires considerable authority as a narrator: if there is a predetermined scheme, it could scarcely be told in any other way than the way in which Schweitzer himself describes it.

\section{David Friedrich Strauss}

So Reimarus comes, for Schweitzer, as a bolt from the blue. Strauss, on the other hand, has a way carefully prepared for him by the rationalism that dominated the end of the eighteenth, and the first third of the nineteenth century. The story, in nuce, runs as follows. The rationalist school tried to preserve both the truth of the Bible, and enlightenment canons of rationality. This entailed maintaining the truth of the events that took place, but explaining them in rational terms: Paulus describes the feeding of the five thousand as the result of a few who had food being inspired to share their lunches. ${ }^{28}$ For Bahrdt, Jesus was standing in the mouth of a cave being passed bread and fish by associates of his secret society inside. ${ }^{29}$

\footnotetext{
26 An account of these responses is given in Buchanan, 'Introduction' to The Goal of Jesus and His Disciples (Leiden: Brill, 1970), pp. 10-27 and Brown, Jesus in European Protestant Thought, pp. 1-16.

27 Quest, 16.

28 Paulus, cited in D.F. Strauss, Life of Jesus Critically Examined, p. 513 and Quest, 52.

29 Bahrdt, cited in Quest, 41.
} 
Schweitzer uses his most vivid descriptions for the rationalists. Franz Reinhard, according to Schweitzer, 'seems to have been haunted by a fear that it might sometime befall him to admit into his mind a thought which was mystical or visionary, not justifiable by the laws of logic and the canons of the critical reason' (Quest, 31). Similarly, Heinrich Paulus, an important player in philosophical scholarship 'had an unconquerable distrust of anything that went outside the boundaries of logical thought' (Quest, 48).

Schweitzer charts the journey after Reimarus from 'earlier rationalism' (mostly Lives of Jesus from the end of the seventeenth century), through fully developed rationalism (Paulus), to 'the last phase of rationalism'. This last phase, crucially, is the immediate precursor to Strauss' work. Hase and Schleiermacher, this last phase's representatives, are paradoxical figures, 'in one respect still wholly dominated by rationalism', but they 'no longer have the same ingenuous confidence in it as their predecessors', so that they 'might, in fact, be described as the sceptics of rationalism' (Quest, 58).

\section{The Characterisation of Strauss}

So Rationalism has run its course showing itself to be inadequate. Even its protagonists are now having a bad conscience about the project. This paves the way for Strauss, perhaps the hero of the Quest, who receives the fullest and most glowing biography.

In order to understand Strauss one must love him. He was not the greatest, and not the deepest, of theologians, but he was the most absolutely sincere. His insight and his errors were alike the insight and the errors of a prophet. And he had a prophet's fate. Disappointment and suffering gave his life its consecration. It unrolls itself before us like a tragedy... (Quest, 68).

Chapter 7, which this quotation begins, is entitled 'David Friedrich Strauss: His Life and His Destiny'. His life is of interest to Schweitzer because of the tension between the great achievement of his Life of Jesus, and his failures as a person. His Life of Jesus 'rendered him famous in a moment-and utterly destroyed his prospects' (Quest, 71). Tragedy struck again as Strauss' disastrous marriage to a famous singer ended in divorce. When he embarked on a political career, he found the vulgarity of his colleagues distasteful, and retreated into more reactionary company. ${ }^{30}$ Finally, he published his

30 Quest, 74. 
Life of Jesus for the German People, ${ }^{31}$ a travesty in Schweitzer's view - a recantation of everything which his 1835 Life of Jesus Critically Examined had stood for. Strauss is a kind of heroic failure.

The heroism of his first Life of Jesus was in its sincerity: it showed Strauss as 'the most sincere of theologians' ${ }^{32}$ Here we see one of Schweitzer's means of narrative creation: his construction of the feelings and motives involved in the questers. This is unexceptional for nineteenth-century theological scholarship. ${ }^{33}$ But it is surprising from our perspective and is one of Schweitzer's most suspect strategies, especially his frequent designations of 'sincere' or 'insincere'. 'Insincerity' is the unkindest cut of all, reserved for conservative supernaturalists and the most desiccated liberals, including Ernest Renan. Sincerity is the great virtue, a feature of the greatness of the national project as whole, and emblematic of its greatest participants, particularly Strauss.

In addition, Strauss is a prime example of how love and hate are driving forces for an author. Schweitzer clearly thought the best Lives were those which had the love or hatred of the authors breathed into them. ${ }^{34}$ Bruno Bauer is a rather obvious instance where we see Schweitzer's narrative imagination writing the plot of Bauer's process of composition (Quest, 153-54): his

outbreaks of bitterness are to be explained by the feelings of repulsion which German apologetic theology inspired in every genuinely honest and thoughtful man by the methods which it adopted in opposing Strauss...A furious hatred, a fierce desire to strip the theologians absolutely bare, carried Bauer much farther than his critical acumen would have led him in cold blood. ${ }^{35}$

31 D.F. Strauss, Das Leben Jesu für das deutsche Volk bearbeitet (Leipzig: Kröner, 1864).

32 Quest, 153 quotes Bauer describing 'the doughty Reimarus with his thoroughgoing honesty'.

33 Another example of the virtue of sincerity in nineteenth century scholarship can be seen in F.W. Farrar's Life of St Augustine (London: Hodder \& Stoughton, 1993 ['1889]), p. 141, where he says of Pelagius: 'This much at least is certain: he was perfectly sincere'. This has its roots in the eighteenth century too: M. Tindal's Christianity as Old as the Creation (1730) is a deistic work which also points throughout to the importance of sincerity. Cf. also J.J. Wettstein, Novum Testamentum Graecum Vol. II (Amsterdam, 1752), p. 873, which talks of the most important characteristics of the NT scholar as "candor, hoc est studium veri simplex et rectum, animusque ab omni studio partium alienissimus'.

34 Quest, 4.

35 'Cold blood' (Kaltblütigkeit) is perhaps significant in that it is the spirit in which Strauss claimed to do his work. See Hodgson's note on the Preface to Vol. I of the 1st German ed.; D.F. Strauss, Life of Jesus Critically Examined, lii. 


\section{Strauss' Discussion of Eschatology}

When it comes to Jesus' eschatology, Strauss follows a different course from normal. Most often, he plays off standard supernatural explanations of the Gospel accounts against the new rationalistic ones, and shows that they are, from his point of view, equally implausible. ${ }^{36}$ But in the case of eschatology, he takes an orthodox view and pits it against the view of the sceptic. Strauss has found an interlocutor more radical than himself. The traditional orthodox approach to the Kingdom, says Strauss, is a non-eschatological, spiritualised Kingdom. The response of the sceptic is-and here Strauss has Reimarus in his sights-that Jesus did not have a spiritual kingdom in mind, but a political one, to be brought about by an overthrow of the current authorities. ${ }^{37}$ Strauss criticises each side for not taking account of the evidence for the other view, and also rejects the idea that Jesus described the Kingdom in different ways at different stages of his ministry. For Strauss, the eschatological kingdom is neither the revolutionary nor the spiritual picture. It is not revolutionary, since it is brought about by God's direct intervention. It is not purely spiritual since it does not come about in this world, but its sphere is the 'supermundane theatre of the regenerated earth'. But when it comes to positive description of the Kingdom, Strauss is less specific. His understanding of Jesus' eschatology shares features of both the worldly and other-worldly models. He talks of a 'catastrophe' and 'unprecedented changes in the external conditions of things', with the 'resurrection of the dead' taking place in this 'supermundane theatre'; 38 yet, he commissions the disciples to proclaim the Kingdom promising them twelve thrones, which, according to Strauss, they could only have understood in thisworldly terms. ${ }^{39}$

But Strauss in his dogmatic reconstruction of eschatology ignores all this. He had grown up in the house of a somewhat liberal mother and a father who 'seems to have hovered between mysticism and orthodoxy'. ${ }^{40}$ In Tübingen, he came particularly under the influence of Schelling, and later he settled as a convinced disciple of

36 For a very typical example see Strauss's treatment of the transfiguration

(Life of Jesus, p. 544).

37 Strauss, Life of Jesus, p. 293.

38 Strauss, Life of Jesus, p. 294.

39 Strauss, Life of Jesus, pp. 293-94.

40 H. Harris, David Friedrich Strauss and His Theology (Cambridge: CUP, 1973), p. 3. 
Hegel. ${ }^{11}$ Some Hegelians believed in personal immortality, but Strauss argued that this was inconsistent, maintaining a monistic view of time, with the eternal and the present being self-identical. The central argument of his dissertation on the 'restoration of all things'42 (which Schweitzer considered lost) was that this future 'restoration' must be de-eschatologised because of the unity between the finite spirit (man) and the infinite spirit (God). ${ }^{43}$ Because the unity of these two spirits is a present reality, there is no need for two distinct entities to be restored in the future. As Hodgson puts it:

Strauss was not an atheist, but he was unable to believe in a transcendent personal God who intervenes supernaturally in the course of nature and history and who reserves eternal blessedness to the end of history, at which time the righteous will be rewarded and sinners condemned... Strauss posited a pantheism that asserted the ultimate identity of God and the world, and immanence of time and eternity. 44

And as expected, what Schweitzer is most concerned with in his treatment of the Life is the emphasis on eschatology. When it comes to Jesus' eschatology, 'Strauss is not only a destroyer of untenable solutions, but also the prophet of coming knowledge' (Quest, 95). As Reimarus was the overture, Strauss was also predictive of the future, flagging up what was to be fully dealt with by Weiss and Schweitzer. Schweitzer identified closely with Strauss: Strauss was also a young and iconoclastic genius who saw that Jesus predicted a catastrophic event in the future which ushered in the age to come, but made the rather dangerous decision that this had no relevance to modern thought. 'Eschatology is the secret motif of The Life of Jesus', Hodgson writes: ${ }^{45}$ meaning, of course, that the secret motif is the elimination of the eschatology of primitive Christianity from contemporary theology, because it was such a stumbling block to the modern mind.

41 Harris, David Friedrich Strauss, pp. 10, 27-29.

42 D.F. Strauss, Die Lehre von der Wiederbringung aller Dinge in ihrer religionsgeschichtlichen Entwicklung (Tübingen, Diss. 1831), reprinted in G. Müller, Identität und Immanenz: Zur Genese der Theologie von David Friedrich Strauss (Zürich: EVZ Verlag, 1968), pp. 50-82.

43 See especially Müller, Identität und Immanenz. Also, see P. Hodgson, 'Editor's Introduction' to The Life of Jesus Critically Examined, pp. xv-xix.

44 Hodgson, 'Editor's Introduction', p. xv.

45 Hodgson, 'Editor's Introduction', p. xviii. 


\section{Johannes Weiss}

During the period of the dominance of liberal Lives, which led up to the rediscovery of eschatology, the quest had in practice ground to a halt. The industry continued, but the books were simply following the pattern established in the 1860s. Here Schweitzer's narrativising artifice is particularly powerful. He presents these liberal Lives of Jesus as indistinct-all clones designed according to an immutable pattern. 'The works of Renan, Strauss, Schenkel, Weizsäcker and Keim are in essence only different ways of carrying out a single ground-plan. To read them one after another is to be simply appalled at the stereotyped uniformity of the world of thought in which they move' (Quest, 200). Schweitzer constructs a consensus based on a rejection of eschatology and a focus on 'an inward Kingdom of repentance' (Quest, 205).46 This goes hand in hand with a bourgeois Jesus who has been stripped of enthusiastic, un-German tendencies.

Side by side with this liberal consensus, though, Schweitzer constructs a plot of developing unease: 'people began to see that the elaborate Lives of Jesus which had hitherto held the field and enjoyed an immortality of revised editions, only masked the fact that the study of the subject was at a standstill' (Quest, 241). We are not sure who these 'people' are who 'began to see', but Schweitzer wants to show that the scales were falling from the eyes of some. And again, Schweitzer's schema is put into operation whereby a school burns itself out as it follows through its approach to its logical conclusion and cannot make any progress.

Enter Johannes Weiss. Son of the conservative NT scholar Bernard Weiss, and son-in-law of the liberal theologian Albrecht Ritschl, Weiss was his own man. ${ }^{47}$ His sketch of Jesus's announcement of God's Kingdom was a complete break from the production line which preceded him. ${ }^{48}$ Schweitzer's treatment of Weiss only occupies a little over three pages (Weiss's book is only 67 pages). But it marks a watershed in Schweitzer's narrative, and

\footnotetext{
46 Schweitzer, Von Reimarus zu Wrede, p. 204: 'ein innerliches Reich der Sinnesänderung'.

47 He has had a considerable influence on twentieth-century NT scholarship both directly and indirectly through his students, not least one Rudolf Bultmann.

48 J. Weiss, Die Predigt Jesu vom Reiche Gottes (Göttingen: Vandenhoeck \& Ruprecht, 1892). English translation by Richard H. Hiers \& D. Larrimore Holland, Jesus' Proclamation of the Kingdom of God (Philadelphia: Fortress, 1971).
} 
represents a new era in the understanding of eschatology. The book is quite simple, and everything is directed to the end of defining Jesus's understanding of the Kingdom. Yet, it is, for Schweitzer, one of the most significant works in the history of theology (Quest, 238). ${ }^{49}$ In his treatment of Reimarus, Schweitzer warned us that despite the verdict on the Fragments at the beginning of the 19th century, Reimarus would eventually be seen to be fundamentally correct: 'Every sentence of Johannes Weiss's Die Predigt Jesu vom Reiche Gottes (1892) is a vindication, a rehabilitation, of Reimarus as a historical thinker' (Quest, 23). Schweitzer had also said in the course of his reading of Strauss's Life of Jesus 'Sometimes one almost seems to be reading Johannes Weiss' (Quest, 92). And Weiss's work has 'an importance equal to that of Strauss's first Life of Jesus' (Quest, 237). As Reimarus and Strauss, Schweitzer knots his three heroes together, creating a relationship between them whereby each anticipates or revisits the key ideas of the others. Schweitzer's innovation is evident here when you consider that while Strauss often draws on Reimarus, ${ }^{50}$ Weiss mentions neither.

\section{Weiss's Eschatological Portrait of Jesus}

The crucial points which most impressed Schweitzer were as follows. First, the bourgeois Jesus who was a sound nineteenth-century man was replaced with a heroic apocalyptic prophet, ${ }^{51}$ who demanded a rejection of the world. ${ }^{52}$ The liberal Lives were doomed to failure and self-contradiction because 'they had to transpose a way of envisaging the world which belonged to a hero and a dreamer to the plane of thought of a rational bourgeois religion' (Quest, 208).

Secondly, the Kingdom is brought about purely by God's activity. No human revolutionary activity or morality can bring it about, nor is Jesus its founder. It is entirely the work of God.

49 Bultmann similarly describes it as 'epoch-making' (Jesus Christ and Mythology [New York: Charles Scribner's Sons, 1958], p. 12).

50 In addition to the references in his Life of Jesus, Strauss wrote a short essay on Reimarus, Hermann Samuel Reimarus and His Apology, translated in Talbert ed., Reimarus: Fragments, pp. 44-58.

51 Weiss describes Jesus's words as 'heroic' (Jesus' Proclamation, p. 112) anticipating Schweitzer's The Mystery of the Kingdom of God, where he describes the aim of the book as 'to depict the figure of Jesus in its overwhelming heroic greatness and to impress it upon the modern age and upon the modern theology' (Mystery, p. 274).

52 Hiers \& Holland, 'Introduction' to Jesus' Proclamation, p. 10, n. 24: 'Both Weiss and Schweitzer understand Jesus to mean that only those who gave up all worldly ties and treasures would be fit to enter the Kingdom.' 
Third, because the present age is still in operation, the Kingdom is purely future. And so, Jesus' Messiahship and designation as 'the Son of Man' were not roles which he had from the beginning; he was to take them up when God brought in the Kingdom at the end of time. Weiss is more sensitive than Schweitzer to the texts that speak of the 'already', the presence of the Kingdom, and he does not ignore them in such a cavalier way as Schweitzer. ${ }^{53}$ Weiss says of Jesus: 'Indeed, he even had moments of prophetic vision when he perceived the opposing kingdom of Satan as already overcome and broken. At such moments as these he declared with daring faith that the Kingdom of God had actually already come'. ${ }^{54}$ (129). But in the final analysis, Weiss too presents an 'either-or': either purely present, or purely future. ${ }^{55}$

Fourthly, the Kingdom is not a spiritual or political reality which can operate in any way within this world; rather it brings this world to an end, replacing this age as a new one dawns. But what did Jesus mean by the Kingdom of God? Here Weiss is hard to pin down. On the one hand, he frequently talks of the 'destruction' of the old world, saying that the old world cannot assimilate the Kingdom of God, and says that the language of palingenesia ('transformation'), should only really be applied to individuals, rather than the world (Jesus' Proclamation, p. 95). He says in his summary 'God will destroy this old world which is ruled and spoiled by the devil, and create a new world'. But he adds, 'mankind will participate in this transformation' (p. 130). On the other hand, he does also equate 'the event of a new creation' with 'the transformation of the world' ( $p$. 93). Indeed, Weiss concedes such a degree of continuity between this age and the age to come that there will still be a land which has a role to play: the territory of Israel will be the sole possession of the meek and will 'arise in a new and glorious splendour, forming the centre of the new Kingdom' (pp. 130-31).

So what did Weiss make of this eschatology personally? Ironically, having gone to the trouble of debunking Ritschl's view of Jesus' eschatology, he takes the view that the only workable dogmatic doctrine of the Kingdom is Ritschl's. He is willing to

53 'He turns a Nelson eye on all the evidence in the Synoptics which proclaims the Kingdom a present reality in the ministry of Jesus.' A.M. Hunter, Interpreting the New Testament. 1900-1950 (London: SCM, 1951), p. 52.

54 Weiss, Jesus' Proclamation, p. 129.

55 Weiss explicitly lays out the options antithetically himself: 'either the basileia is here or it is not here' (Jesus' Proclamation, p. 73). 
abandon Jesus's eschatology, and replaces it with a personal one, where everyone should constantly be aware of his own mortality:

We do not share the eschatological attitude, namely, that to schema tou kosmou toutou paragei. We no longer pray 'May grace come and this world pass away', but we pass our lives in the joyful confidence that this world will evermore be the showplace of the people of God...The world will further endure, but we, as individuals, will soon leave it. Thereby, we will at least approximate Jesus' attitude in a different sense, if we make the basis of our life: 'Live as though you were dying' (Jesus' Proclamation, pp. 135-36).

Weiss flatters himself by describing his attitude as 'approximating to that of Jesus': it is in fact the polar opposite of what he thinks Jesus believed. Whereas Weiss's Jesus believed in the end of the world, and the eternity of humanity, Weiss himself argues that ethics should be grounded in the eternity of the world, and the brevity of human life. So Weiss, like Strauss, has built up the house of apocalyptic eschatology, only to knock it down again.

\section{The Location of Weiss in Schweitzer's Narrative}

In Schweitzer's short discussion of Weiss, Weiss is spoken of in glowing terms. He has clearly articulated the concepts that have remained distorted or muted in the quest thus far. On the other hand, having praised Weiss, Schweitzer comes to bury him. In Schweitzer's presentation of his own position, he interweaves his own view with discussion of William Wrede, but Weiss is scarcely mentioned. After his three-page discussion of Weiss, there is only one paragraph where Schweitzer talks positively about him (Quest, 356). In the main, however, he is the ladder up which Schweitzer has climbed, only to be kicked away afterwards. The few mentions of Weiss in Schweitzer's long penultimate chapter are critical, his chief objection being that Weiss did not apply his theory to Jesus's actions as well as his teaching. Later, Schweitzer criticises him again for misconstruing Jesus's view of the atonement $(388, n$. 1). However, Schweitzer 'may have exaggerated the difference between konsequente Eschatologie and Weiss's theory'. 56 Weiss places Jesus's exorcisms, for example, as eschatological activity which announces and even mirrors the coming of the Kingdom. He sees Jesus's death as a self-consciously eschatological event, even though he understands Jesus's death differently from Schweitzer. ${ }^{57}$

56 Hiers and Holland, 'Introduction' to Jesus' Proclamation, p. 32.

57 Ibid., pp. 32-33. 
So Schweitzer claims the eschatological high-ground over Weiss rather disingenuously.

So Schweitzer's location of Weiss in his narrative is ambiguous: for the first two-thirds of the story, Reimarus and Strauss are his typological forbears, and he is the champion of a true understanding of eschatology. But in the end, he disappears from view.

\section{Albert Schweitzer}

So Weiss's disappearance means that he cannot be the climactic figure he might have been. Schweitzer's title implies that William Wrede might be the one. Wrede's The Messianic Secret in the Gospels $^{58}$ was published on the same day as Schweitzer's rather similarly titled dissertation. But Schweitzer disagrees with Wrede's central thesis that the Messiahship of Jesus was a creation of the early church, that the puzzles and problems of the Gospel narratives originate in their composition, not in the ministry of Jesus. So Wrede is not the narrative's climax. One of the first reviews of Quest by Paul Wernle, ${ }^{59}$ draws attention to the irony in the original title (From Reimarus to Wrede), considering that Wrede is by no means a survivor of the slaughter which Schweitzer perpetrates on the Lifeof-Jesus battlefield. He draws the conclusion that 'The title of the book, From Reimarus to Wrede, then, is false: it should be called From Reimarus to Albert Schweitzer' ${ }^{60}$ When one considers the work as descriptive of a narrative from Reimarus to Wrede, the quest as a whole is, just as many of its constituent components were, a heroic failure. But this whole quest-narrative is framed by Schweitzer's own presentation of Jesus' ministry, which ironises yet redeems the preceding. Schweitzer sees value in the bunglings of the nineteenth century since they led ineluctably to his solution. The English title, adopting the term 'quest', highlights this point.

We therefore come to the problem of Schweitzer's own selflocation in the narrative. C.K. Barrett in his eulogy on Schweitzer notes 'Perhaps a writer-historian or theologian or both-is fortunate when he can start with the conviction that his

$58 \mathrm{~W}$. Wrede, Das Messiasgeheimnis in den Evangelien (Göttingen: Vandenhoeck \& Ruprecht, 1901).

59 TLZ 18 (1906), 501-506.

60 Wernle, p. 502. Robert Morgan makes the same point in his 'From Reimarus to Sanders' in R.S. Barbour, ed. The Kingdom of God and Human Society (Edinburgh: T. \& T. Clark, 1993), p. 81. 
predecessors and contemporaries are fundamentally in error. It makes for clarity of analysis.' 61 Clarity of analysis, perhaps, but it poses the question of how the author is to present himself. Schweitzer never admits that he is the real hero. In the long final section, the Sketch (i.e. Schweitzer's A Sketch of the Life of Jesus) is the protagonist: 'the Sketch shows...' is how he repeatedly puts it. Schweitzer has intruded into the narrative uninvited (he stood outside the sequence promised in the title) and the reader who was promised a history-of-research, in the subtitle 'A History of Research into the Life of Jesus', has been treated to 75 pages of Schweitzer's Sketch, smuggled inside an analysis of Wrede's work.

Schweitzer's heroic achievement is highlighted by the way he ends the book. In his conclusion, Schweitzer ends not with a plea to the reader to sift the evidence that Schweitzer has provided, and agree with him. Rather, the presentation is of a German liberal theology that has, like it or not, already come to the end of its life. Its demise is a fait accompli which Schweitzer's text does not claim to contribute to, but rather announces. Schweitzer proclaims the destruction of the bourgeois, German Jesus of the nineteenth century - 'a figure designed by rationalism, endowed with life by liberalism, and clothed by modern theology in historical garb'.62 It had not been destroyed from outside; it had fallen apart from within. Wrede and Schweitzer have only shown what was already the case.

\section{Schweitzer's Eschatology}

It is widely held that Schweitzer's view of the nature of Jewish, and therefore Christian expectation was the end of the space-time universe: 'eschatology as the climax of Israel's history, involving the end of the space-time universe'.63 'Schweitzer's Jesus...prophesied the end of the cosmos' ${ }^{64}$ N.T. Wright describes what is now the dominant picture of Jewish eschatology in current researchrestoration, a new and better age, the rebuilding or purification of the temple, and the defeat or conversion of the gentiles-and pits it antithetically against Schweitzer's presentation. If Schweitzer had understood that this was the nature of Jewish eschatological

61 C.K. Barrett, 'Albert Schweitzer and the New Testament', Expository Times 87 (1975), pp. 5-6.

62 Quest, 396.

63 N.T. Wright, Jesus and the Victory of God (Minneapolis: Fortress, 1996), p. 208.

64 Wright, Jesus and the Victory of God, p. 223. 
expectation, Wright argues, 'the entire course of New Testament studies in the twentieth century would have been different' ${ }^{65}$ Again: 'Schweitzer was right, I believe, when at the beginning of the twentieth century he drew attention to apocalyptic as the matrix of early Christianity. It is now high time, as the century draws to its close, to state, against Schweitzer, what that apocalyptic matrix actually was and meant.'66 I think, however, there are grounds for thinking that Schweitzer's presentation was not so univocal as the 'end of the space-time universe' ${ }^{67}$ Doubts have already been raised about Wright's presentation in a recent essay by Dale C. Allison. ${ }^{68}$

Schweitzer's enthusiasm for Weiss's presentation of eschatology hints that they both accept the continuity which we have seen in Weiss: the description of transformation, rather than annihilation and recreation. Weiss even sees a renewed land of Israel having a role. But like Weiss, Schweitzer never devotes special attention to describing the nature of the Kingdom, except in scattered parts of The Mystery of the Kingdom of God. In Quest Schweitzer presents Weiss's views favourably, and gives the impression that he agrees with him. Schweitzer describes Weiss's portrait like this: 'The transcendental character of the expectation consists precisely in this: that the state and all earthly institutions, conditions and benefits shall either not exist at all, or shall exist only in a sublimated form.' (239) Later on, the new world is described as 'supra-mundane', 'supernatural' (371). Most strikingly 'all natural relationships are abolished...all is reign', ${ }^{69}$ i.e. all in various degrees reign with the Son of Man on his throne. And in Mystery of the Kingdom of God, the Kingdom comes with 'a cosmic catastrophe in which God's omnipotence should bring to its conclusion the work he had undertaken', and finally: 'Jesus no longer conceives the Kingdom as an intervention of God in the history of the nations, as did the

65 N.T. Wright, The New Testament and the People of God (Minneapolis: Fortress, 1992), pp. 333-34.

66 Wright, New Testament and the People of God, p. 334.

67 Wright also uses this phrase in New Testament and the People of God, p. 333; cf. p. 332: 'an abandonment...of the space-time order as a whole'.

68 Dale C. Allison, 'Jesus and the Victory of Apocalyptic', in Carey C. Newman, ed. Jesus and the Restoration of Israel: A Critical Assessment of N.T. Wright's Jesus and the Victory of God (Downers Grove, IL: IVP, 1999), esp. pp. 128-30.

69 Schweitzer explains this briefly in Mystery, pp. 76-77. 
prophets; but rather as a final cosmic catastrophe. His eschatology is the apocalyptic of the book of Daniel.' 70

So far Schweitzer as he is normally understood. But Schweitzer does not see the discontinuity as so stark as an 'end of the spacetime universe'. He still leaves open the possibility that the Kingdom has features of this world: but of course, they exist 'only in a sublimated form'. This is a tricky phrase, because W. Lowrie (translating Mystery of the Kingdom of God) and W. Montgomerie (translating Quest) translate various different German words with 'sublimation'. In Mystery, for example, Schweitzer criticises the liberal tendency toward the Sublimierung of eschatology, by which he means its spiritualisation.71 But on the other hand, he allows the possibility, as we have seen, for the existence of earthly institutions 'in sublimated form' (in verklärter Form): that is, in a transfigured form (Quest, 239), which suggests an analogy with the transfiguration of Jesus. And he describes the deferral of Jewish eschatological hope from this world to the the world to come as Transzendentierung, again translated by Montgomery as 'sublimation' (Quest, 246). What this means might be explicated by Schweitzer's description of what takes place at the coming of the Kingdom as 'the transformation of the whole form of existence'. 72

By the coming of the Kingdom of God, the earthly form of existence in general must be raised to another and an incomparably higher estate. ${ }^{73}$

The nature of the Kingdom as Schweitzer describes it is that it consists of the ontology of this world being taken up into an unimagniable higher mode of existence. ${ }^{74}$ Here is the tension: the form of existence of this world is not abolished but raised to a higher level, yet this new form cannot be compared with the old.

Summing up, it is certainly not my intention to argue that Schweitzer is actually referring to a this-worldly eschatology. However, a slight corrective is that he does not describe a completely new world which bears no relation to the old. It appears Schweitzer did not necessarily think that Jesus thought in terms of the end of the space-time universe, like the annihilation of planets as in Hollywood films, or even the old Stoic view of ekpurosis. But the

70 Schweitzer, Mystery, pp. 114-15.

71 Schweitzer, Mystery, p. 85; Messianitäts- und Leidensgeheimnis, p. 222.

72 'Die Veränderung der ganzen Existenzform'.

73 Schweitzer, Mystery, p. 206; Messianitäts- und Leidensgeheimnis, p. 297.

74 Schweitzer (ibid.) notes that those who have died before the coming of the Kingdom will experience a resurrection. 
renewal and transformation of the earth has to be balanced with the fact that there is no society to speak of, no natural relationships. Certainly more needs to be said on this subject than can be argued here. And it may even be the case that Schweitzer himself is unclear on the point.

But again, as we have seen with Strauss and Weiss, this is all of little interest to Schweitzer personally and dogmatically. Schweitzer is quite hostile to dogma anyway, but does consider the heroic drive that Jesus has as a result of his eschatological mindset something admirable. And this is what Schweitzer derives from it personally. Weiss had an eschatological view of Jesus, but a Ritschlian view of the Kingdom, which was a very staid ethic compared with Schweitzer's dynamic, manic activism. Weiss concludes his book with an affirmation of the world, Schweitzer with the opposite.

\section{Conclusion}

So, to conclude, the critical agenda of Schweitzer's book takes us from Reimarus's political eschatology through Strauss's claim that the Kingdom is brought about by God himself on a supermundane stage, through Weiss's discovery that that it takes place wholly in the future, all of which Schweitzer sets in the context of the whole teaching and ministry of Jesus. But the dogmatic agenda is that all of these figures - the heroes of the book-have divorced these views of eschatology from their dogmatics: Reimarus with his deistic natural religion, Strauss with his anti-eschatological Hegelianism, Weiss with his Ritschlian ethics, and Schweitzer with his worlddenying radicalism.

A General Session at the 1999 SBL Meeting on 'The New Millennium: The Origins and Persistence of Biblical Apocalypticism' addressed the question: 'How is it that an archaic world view, forged in ancient Jewish circles, and exported into the world by the early Christians, has persisted into our own time-indeed into the Third Millennium?'75 But in contrast to the surprised tone of the question posed here, the eschatological component of apocalypticism should not be seen as an outmoded and primitive element of theology. The thoughts of Jesus himself must continue govern our theology. Hans Frei argues that one of the principal aims of many of the questers

75 '1999 AAR/SBL Annual Meeting Program', November 20-23, 1999, p. 17. 
was to undermine the uniqueness of Christ. ${ }^{76}$ David Larrimore Holland notes that the authority of Scripture was being subjected to violent attack. ${ }^{77}$ It is argued here that a chief intention (the 'secret motif 78 perhaps) of Schweitzer's work was to dismantle futuristic eschatology. In this he followed in the footsteps of his three favourite predecessors. But, just as the first Christians had to deal with thoe scoffers who argued that God's future judgment would never really come, so it is also vitale that Christian theology today faces up to the task of defending and proclaiming the eschatology to which Schweitzer and the nineteenth century were so implacably opposed. 79

76 H. Frei, 'David Friedrich Strauss', in N. Smart et al., eds. Nineteenth Century Religious Thought in the West. Vol. I (CUP, 1985), pp. 215-60.

77 D.L. Holland, 'History, Theology and the Kingdom of God: A Contribution of Johannes Weiss to Twentieth Century Theology', Biblical Research 13 (1968), 54-68.

78 To pick up Hodgson's description of the role of eschatology in Strauss's Life of Jesus (see above).

79 I am particularly grateful to Drs Peter Head, Jonathan Long, and James Carleton Paget for comments on this article in its various stages, as well as to the Historical Jesus section of the British New Testament Conference and the Research Seminar in the Department of German, Durham University for their welcome comments on this material. 